\title{
QUALITY OF Hovenia dulcis Thunb. ROUND FENCE POSTS SUBMITTED TO PRESERVATIVE TREATMENT
}

\author{
Amanda Grassmann da Silveira ${ }^{1 *}$, Talita Baldin ${ }^{1}$, Bibiana Regina Argenta Vidrano ${ }^{1}$, Elio José Santini ${ }^{1}$, Maiara \\ Talgatti $^{1}$, Rômulo Trevisan ${ }^{2}$ \\ ${ }^{1}$ Federal University of Santa Maria, Santa Maria, Rio Grande do Sul, Brazil - amandagrassmann@ gmail.com*; talita.baldin@ @otmail.com; \\ bibianaargenta@gmail.com; ejsantini@gmail.com; maiara.talgatti@hotmail.com \\ ${ }^{2}$ Federal University of Santa Maria, Frederico Westphalen, Rio Grande do Sul, Brazil - romulo_trevisan@yahoo.com.br
}

Recebido para publicação: 10/01/2017 - Aceito para publicação: 27/11/2017

\begin{abstract}
This study aimed to test the hypothesis regarding the quality of Hovenia dulcis fence posts, which states that it varies according to the treatment period when subjected to the sap displacement method.. The experiment began with 15 round fence posts distributed vertically in tank containing copper sulfate, sodium dichromate and boric acid (CCB) solution at $2.5 \%$ concentration. In order to verify the influence of time on the efficiency of the method, the posts stayed in the preservative solution for periods of 3, 6, 9, 12 and 15 days, which were assessed. Penetration and retention in three positions were analyzed, which corresponded to the regions of base, middle and top parts. With regards to treated wood, samples of each piece were prepared for testing in field test. Then, weight loss and bending properties were assessed. According to the results of penetration and retention, wood treated on the period of 15 days is the only one that can be used directly with the soil. After assessment of the weight loss, the periods of 12 and 15 days of treatment increased the classification of wood from moderately to strong resistant. The bending test showed significant reduction in rigidity and strength of the material, even in the treated ones, which demonstrates that the forest environment in which samples were exposed promoted the process of wood decomposition.

Keywords: Durability, wood preservation, Japanese raisin tree, decomposition.
\end{abstract}

\section{Resumo}

Qualidade de mourões de Hovenia dulcis submetidos a tratamento preservativo. Este estudo teve como objetivo testar a hipótese de que a qualidade de mourões de Hovenia dulcis, submetidos ao tratamento preservativo por substituição de seiva, varia de acordo com o período de tratamento. O experimento começou com 15 mourões distribuídos verticalmente em tonéis contendo solução de sulfato de cobre, dicromato de sódio e ácido bórico (CCB) na concentração de 2,5\%. A fim de verificar a influência do tempo na eficiência do método, foram determinados os períodos de 3, 6, 9, 12 e 15 dias de permanência das peças na solução preservativa. Foram analisadas a penetração e a retenção em três posições, que correspondem às regiões da base, meio e topo das peças. Da madeira tratada, foram produzidas amostras de cada peça para o ensaio em campo de apodrecimento. Posteriormente, foram avaliadas a perda de massa e a flexão estática. De acordo com os resultados da penetração e retenção, somente a madeira tratada pelo período de 15 dias pode ser utilizada em contato direto com o solo. Quando avaliada a perda de massa, os períodos 12 e 15 dias de tratamento elevaram a classificação da madeira de moderadamente resistente para resistente. Já o ensaio de flexão estática revelou redução na rigidez e na resistência do material, mesmo dos preservados, demonstrando que o ambiente florestal no qual as amostras foram expostas promoveu o processo de decomposição da madeira.

Palavras-chave: Durabilidade, preservação da madeira, uva-do-japão, decomposição.

\section{INTRODUCTION}

Wood is a renewable material, and its physical-mechanical and anatomical properties allow its use in various purposes such as in construction, furniture industry and pulp and paper production. It is also an important raw material for energy production. When compared to concrete, plastic, steel and aluminum, wood has numerous advantages, such as appearance, high mechanical strength, easy workability, as well as being a good thermal insulator. To a lesser extent, some disadvantages may also be mentioned, especially regarding its low natural durability, cracks and warping (VIDAL et al., 2015).

Deterioration of wood is a process in which its properties change due to physical, chemical, mechanical or biological agents; the latter being of greater economic importance (MILANI; KRIPKA, 2012). The biological agents, mainly fungi and termites, attack the wood to use its constituents as an energy source as well as for shelter, and physical and chemical agents act together with them, accelerating the rotting of the material (CLAUSEN; GLASS, 2012).

FLORESTA, Curitiba, PR, v. 48, n. 1, p. 59-66 jan./mar. 2018

Silveira. A. G. et al.

ISSN eletrônico 1982-4688

DOI: $10.5380 /$ rf.v48 i1.50118 
Wood can be protected in order to increase its length of service. The most common method is chemical preservation (LIIBERT et al., 2011). This protection is crucial for species of low natural resistance or that contains high quantity of sapwood. The treatment effectiveness is assessed by the retention and penetration of preservative products, guaranteed by the minimum levels recommended by technical regulations, according to the class of use of the material (CLAUSEN; GLASS, 2012).

Wood of Hovenia dulcis Thunb., popularly known as Japanese raisin tree, presents great quality for rural construction and woodwork. According to studies of Vivian et al. (2011), its physical-mechanical characteristics are similar to those of Cordia trichotoma, which is why the wood and furniture industry in the mountainous region of Rio Grande do Sul, Brazil, has already been planting this species on a small scale, Up to this date, it has been obtaining good results. This wood presents potential for use in construction, carpentry, beams, rafters, boards, flooring, fence posts, and manufacture of furniture and laminated floors, in addition to its use in the pulp and paper industry.

Species with rapid growth and good quality wood, as Hovenia dulcis, are excellent choices for supplying of roundwood to companies and small farmers. According to Vidal et al. (2015), in the forestry segment of treated wood, there is a gradual replacement of native species by those of rapid growth with similar characteristics and greater availability. The most common use of roundwood post occurs in the production of poles for rural electrification, fence posts, supports for vines, and foundations in rustic constructions. Because of the use versatility of this material, it needs to be properly treated, guaranteeing the desired durability (MODES et al., 2011).

According to Melo et al. (2010), the efficiency of the methods and preservative products applied to the wood can be determined by tests in known locations, such as field test, in which wood is exposed to the soil, to environmental weathering and to wood destroying organisms. This study aimed to test the hypothesis regarding the quality of Hovenia dulcis fence posts, which states that it varies according to the treatment period when subjected to the sap displacement method.

\section{MATERIAL AND METHODS}

The raw material was collected in Hovenia dulcis plantations, located at the State Agricultural Research Foundation - Research Center for Forest Resources (FEPAGRO - Fundação Estadual de Pesquisa Agropecuária Centro de Pesquisa em Recursos Florestais) in the municipality of Santa Maria, Rio Grande do Sul state, Brazil. Five trees were selected according to certain criteria, such as diameter at breast height (DBH), straightness, and healthy appearance of its trunk.

The trees were cut into 15 logs of 1.5 meters of length; size indicated for stakes to electric fences in the landscaping area. As soon as the material was peeled, the cell layer of the cambium was removed and sent to preservative treatment by the sap replacement method, which occurred around 4 hours after cut. The treatment began with 15 round fence posts vertically distributed in tanks of 100 liters that contained copper sulfate, sodium dichromate and boric acid (CCB) solution at $2.5 \%$ concentration. The posts were placed at $50 \mathrm{~cm}$ of height in contact with the solution.

In order to check the influence of the period in the material treatment, three logs in contact with the preservative were removed every 3 days, which resulted in the following treatments: T0 = natural resistance; $\mathrm{T} 1=3$ days of treatment; $\mathrm{T} 2=6$ days of treatment; $\mathrm{T} 3=9$ days of treatment; $\mathrm{T} 4=12$ days of treatment and $\mathrm{T} 5=15$ days of treatment.

As soon as the preservation method period was finalized, the material was dried for CCB (copper sulfate, sodium dichromate and boric acid) mixture fixation. Later, disks for assessment of the preservative treatment and field test samples were made. Chemical analyses were performed in order to determine the penetration and retention of the CCB in the treated parts. For that, two disks removed from fence post in three positions were used. The positions corresponded to the base, middle and top of the piece $(0.10,0.75$ and $1.3 \mathrm{~m})$. This procedure was meant to demonstrate if the treatment was equally received over the whole length of the pieces.

The penetration was verified by colorimetric reactions of copper element, following the indications of the Brazilian Regulatory Standard (NBR - Norma Brasileira) of Brazilian Association of Technical Standards (ABNT - Associação Brasileira de Normas Técnicas, 2013). To measure the depth reached by the preservative, the pieces were marked at random in two diameters perpendicular to each other, and the readings were taken on those diameters. The average value of the readings of each disk represented how much of the chemical element penetrated in the wood.

In order to obtain the retention value of each wood, samples from each disk were taken in the dimensions of $2.0 \times 2.0 \times 2.0 \mathrm{~cm}$ (radial $\times$ tangential $\times$ longitudinal), and then sent to the laboratory, where readings of spectrometry of atomic absorption were taken. From the obtained data, retention calculations were executed, as described by Paes et al. (2008). 
The field test was installed in a recovered forest fragment in the municipality of Santa Maria, Rio Grande do Sul, Brazil, in a soil of textural class loam with $\mathrm{pH}$ 4.7. Information regarding the main attributes of the soil in the area is described in Table 1. Samples removed from the entire treated part were vertically fixed up in half of its length $(15 \mathrm{~cm})$ and spaced $30 \mathrm{~cm}$ apart. They remained exposed for 120 days.

Table 1. Attributes of the soil.

Tabela 1. Atributos do solo.

\begin{tabular}{|c|c|c|c|c|c|c|c|}
\hline $\begin{array}{c}\text { Soil } \\
\text { moisture } \\
(\%)\end{array}$ & $\begin{array}{c}\text { Bulk } \\
\text { density } \\
\left(\mathrm{g} \mathrm{cm}^{-3}\right)\end{array}$ & $\begin{array}{c}\begin{array}{c}\text { Total } \\
\text { porosity }\end{array} \\
\left(\mathrm{cm}^{3} \mathrm{~cm}^{-3}\right) \\
\end{array}$ & $\begin{array}{c}\text { Organic } \\
\text { matter } \\
(\%)\end{array}$ & $\begin{array}{l}\text { Sum of bases } \\
\quad\left(\mathrm{mg} \mathrm{dm}^{\mathbf{3}}\right)\end{array}$ & $\begin{array}{c}\text { CECe } \\
\left(\mathrm{cmol}_{\mathrm{c}}\right. \\
\left.\mathrm{dm}^{3}\right)\end{array}$ & $\begin{array}{c}\text { CEC pH } \\
7\end{array}$ & $\begin{array}{c}\text { Base } \\
\text { saturation } \\
(\%)\end{array}$ \\
\hline 27.9 & 1.20 & 0.53 & 3.3 & 20 & 7 & 18.5 & 25.8 \\
\hline $\begin{array}{c}\mathbf{P} \\
(\mathrm{mg} \\
\left.\mathrm{dm}^{3}\right) \\
\end{array}$ & $\underset{\left(\mathrm{cmol}_{\mathrm{c}} \mathbf{d m}^{3}\right)}{\mathrm{K}}$ & $\begin{array}{c}\mathrm{Ca} \\
\left(\mathrm{cmol}_{\mathrm{c}}\right. \\
\left.\mathrm{dm}^{3}\right)\end{array}$ & $\begin{array}{c}\mathrm{Mg} \\
\left(\mathrm{cmol}_{\mathrm{c}}\right. \\
\left.\mathrm{dm}^{3}\right) \\
\end{array}$ & $\begin{array}{c}\text { Al } \\
\left.\left(\mathrm{cmolc}_{\mathrm{dm}}\right)^{3}\right)\end{array}$ & $\begin{array}{c}\mathrm{H}+\mathrm{Al} \\
\left(\mathrm{cmol}_{\mathrm{c}}\right. \\
\left.\mathrm{dm}^{3}\right)\end{array}$ & $\begin{array}{c}\text { Al } \\
\text { saturation } \\
(\%)\end{array}$ & $\begin{array}{c}\text { Clay } \\
\text { content } \\
(\%)\end{array}$ \\
\hline 6 & 76 & 3.9 & 0.6 & 2.2 & 13.7 & 31.4 & 22 \\
\hline
\end{tabular}

CECe: effective cation exchange capacity; $\mathrm{CEC} \mathrm{pH}$ 7: cation exchange capacity at $\mathrm{pH} 7.0$

Wood specimens before and after field exposure were dried in oven at $103 \pm 2{ }^{\circ} \mathrm{C}$ to obtain the dry mass. According to the difference between the initial and final dry weight, the weight loss was obtained. To assess the resistance of natural and treated logs during the exposure period, the wood weight loss was compared with the amounts presented by the American Society for Testing and Materials (ASTM D-2017, 2005) (Table 2).

Table 2. Wood decay resistance class.

Tabela 2. Classes de resistência da madeira.

\begin{tabular}{ccc} 
Class of Resistance & $\begin{array}{c}\text { Average Weight } \\
\text { Loss (\%) }\end{array}$ & $\begin{array}{c}\text { Average } \\
\text { Residual } \\
\text { Weight (\%) }\end{array}$ \\
\hline Highly resistant & $0-10$ & $90-100$ \\
Resistant & $11-24$ & $76-89$ \\
Moderately resistant & $25-44$ & $56-75$ \\
Slightly resistant or & $\geq 45$ & $\leq 55$ \\
Non resistant & & \\
\hline
\end{tabular}

Source: ASTM D-2017 (2005).

The bending test followed the ASTM D-143 (2005) with adaptations. Forty-nine samples constituted the sapwood, with dimensions of $2.5 \times 2.5 \times 30 \mathrm{~cm}$. Seven were used as control treatment, with no exposure to the elements, and 42 were submitted to exposure. The test was performed in a universal mechanical testing machine, with automated data acquisition system.

Data were assessed by the Shapiro-Wilk test, and data normality was verified at $5 \%$ probability. The penetration and retention of the pieces were analyzed by a completely randomized design in factorial arrangement of $3 \times 5$ ( 3 positions and 5 length of stay in the preservative solution). The means of these variables were assessed by the $t$ test. For the assessments of weight loss and bending test, the analysis of variance of means was performed and the null hypothesis was rejected, which showed there is a significant difference between the treatments. The Tukey test (5\%) was used to assess the means.

\section{RESULTS}

\section{Efficiency of preservative treatment}

According to the analysis of variance, a significant interaction between the treatment time and the fence post position was observed. Penetration values are shown in Table 3. In general, the penetration of the elements showed distinct behavior with regards to preservative exposure time and position on the piece. 
Table 3. Comparison of averages for penetration in different positions and treatment time.

Tabela 3. Comparação de médias para penetração em diferentes posições e tempo de tratamento.

\begin{tabular}{cccc}
\hline \multirow{2}{*}{$\begin{array}{c}\text { Time } \\
\text { day })\end{array}$} & \multicolumn{3}{c}{ Average penetration $(\mathbf{m m})$} \\
\cline { 2 - 4 } & Base & Middle & Top \\
\hline 3 & $25.16 \mathrm{Ac}$ & $4.66 \mathrm{Bb}$ & $2.3 \mathrm{Bb}$ \\
6 & $26.58 \mathrm{Ac}$ & $6.25 \mathrm{Bb}$ & $3.5 \mathrm{Ba}$ \\
9 & $40.33 \mathrm{Aa}$ & $6.91 \mathrm{Bb}$ & $2.3 \mathrm{Ba}$ \\
12 & $35.25 \mathrm{Aab}$ & $8.66 \mathrm{Bab}$ & $4.2 \mathrm{Ba}$ \\
15 & $30.61 \mathrm{Abc}$ & $14.08 \mathrm{Ba}$ & $6.1 \mathrm{Ca}$ \\
\hline
\end{tabular}

Averages followed by the same capital letter per line or lower case letter per column did not differ by the Tukey's test ( $\mathrm{p}>0.05$ ).

The penetration in the base in the used concentration was satisfactory for all times, reducing over the length of the piece. Only one value in accord with the recommendation was verified for the middle of the fence post, which was obtained after 15 days. All values for the top were considered insufficient to guarantee adequate protection of the wood.

The treatment had deeper penetration in the base of the pieces, i.e., in the part that remained in direct contact with the treatment solution. The increment in penetration occurred in treatment time of 3 days. Times of 9 and 12 days had higher averages in base, when compared to treatment time of 15 days. However, the latter showed greater homogeneity in the results compared to the assessment of all positions of the piece. Thus, it was considered more efficient.

The analysis of the variance of the effects of position and time indicated the existence of significant interaction between these factors. Table 4 shows the average retention in $\mathrm{kg} \mathrm{m}^{-3}$ of the CCB solution for each treatment of the post fences of Hovenia dulcis. The minimum retention recommended by the NBR 6232 (ABNT, 2013 ) is $6.5 \mathrm{~kg}$ of active ingredients (ai) $\mathrm{m}^{-3}$.

Table 4. Comparison of averages for retention in different positions and treatment time.

Tabela 4. Comparação de médias para penetração em diferentes posições e tempo de tratamento.

\begin{tabular}{cccc}
\hline \multirow{2}{*}{$\begin{array}{c}\text { Time } \\
\text { day })\end{array}$} & \multicolumn{3}{c}{ Average retention $\left(\mathbf{k g ~ m}^{\mathbf{3}}\right)$} \\
\cline { 2 - 3 } & Base & Middle & Top \\
\hline 3 & $3.86 \mathrm{Ac}$ & $1.63 \mathrm{Ba}$ & $0.33 \mathrm{Ca}$ \\
6 & $5.48 \mathrm{Ab}$ & $1.73 \mathrm{Ba}$ & $0.43 \mathrm{Ca}$ \\
9 & $5.22 \mathrm{Ab}$ & $1.30 \mathrm{Ba}$ & $0.42 \mathrm{Ba}$ \\
12 & $5.47 \mathrm{Ab}$ & $1.29 \mathrm{Ba}$ & $0.42 \mathrm{Ba}$ \\
15 & $7.27 \mathrm{Aa}$ & $1.57 \mathrm{Ba}$ & $0.72 \mathrm{Ba}$ \\
\hline
\end{tabular}

Averages followed by the same capital letter per line or lower case letter per column did not differ by the Tukey's test ( $\mathrm{p}>0.05$ ).

Parts treated in the period of 15 days with samples from the base were the only ones that showed satisfactory retention results, as recommended by the NBR 6232, (ABNT, 2013). Thus, they are indicated for use in direct contact with the soil. The results related to other periods and locations are below the minimum set. Therefore, the use of wood in environments susceptible to attacks by wood destroying organisms is forbidden.

\section{Weight loss}

Results obtained for the weight loss percentage for different periods are shown in Table 5. When the wood was kept in contact with the preservative solution for 3, 6 and 9 days, weight loss decreased in comparison with the control. These results indicate the ineffectiveness of the treatment and make the preservation procedures unnecessary.

Table 5. Averages of wood weight loss according to preservative treatment periods.

Tabela 5. Médias da perda de massa da madeira de acordo com períodos de tratamento preservativo.

\begin{tabular}{cc}
\hline Treatments & Weight Loss (\%) \\
\hline Control & $35.13 \mathrm{a}$ \\
3 days & $34.27 \mathrm{a}$ \\
6 days & $31.25 \mathrm{ab}$ \\
9 days & $26.94 \mathrm{abc}$ \\
\hline
\end{tabular}


Averages followed by the same letter did not differ by the Tukey’s test $(\mathrm{p}>0.05)$.

Even though the material treated for 9 days has showed to be numerically better, it remained in the moderate resistance class. It did not differ with the treatments mentioned above. In the treatments of 12 to 15 days, the weight loss decreased and achieved the classification of resistant wood (Figure 1).

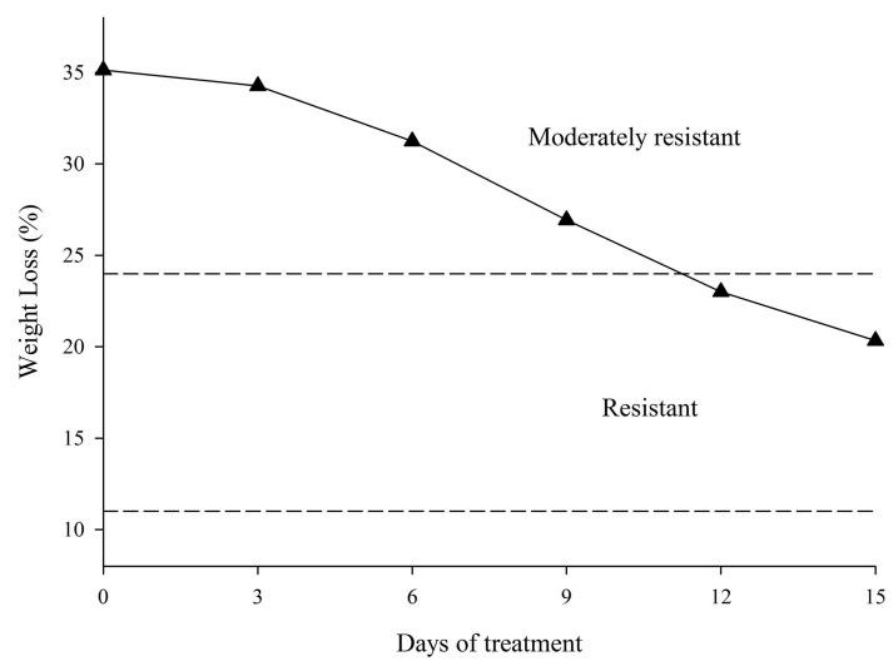

Figure 1. Relation between weight loss and treatment period.

Figura 1. Relação entre a perda de massa e o período de tratamento.

\section{Static bending}

The assessment of the static bending revealed wood modulus of rupture values (MOR), elasticity modulus (MOE) and tension in the proportional limit $(\sigma L P)$. This information is presented in Table 6. The period in the field test generated changes in the wood, which affected the mechanical properties studied; i.e., the modulus of rupture and the elasticity of the wood, after exposure of 120 days to the forest environment. The tension in the proportional limit, another modification after exposure, decreased $80 \%$ in relation to the initial values of the property.

Table 6. Bending of Hovenia dulcis wood; average values of MOR, MOE and $\sigma \mathrm{LP}$.

Tabela 6. Flexão estática da madeira de Hovenia dulcis; valores médios de MOR, MOE e $\sigma \mathrm{LP}$.

\begin{tabular}{cccc}
\hline Treatments & MOR $($ MPa) & MOE $($ MPa) & бLP (MPa) \\
\hline Control & $104.56 \mathrm{a}$ & $9.715 \mathrm{a}$ & $65.10 \mathrm{a}$ \\
Non treated wood & $14.08 \mathrm{~b}$ & $3.334 \mathrm{~b}$ & $13.51 \mathrm{~b}$ \\
3 days & $23.27 \mathrm{~b}$ & $6.533 \mathrm{ab}$ & $18.97 \mathrm{~b}$ \\
6 days & $33.34 \mathrm{ab}$ & $6.122 \mathrm{ab}$ & $31.87 \mathrm{ab}$ \\
9 days & $40.49 \mathrm{ab}$ & $6.267 \mathrm{ab}$ & $32.37 \mathrm{ab}$ \\
12 days & $41.47 \mathrm{ab}$ & $6.777 \mathrm{ab}$ & $39.70 \mathrm{ab}$ \\
15 days & $42.66 \mathrm{ab}$ & $7.017 \mathrm{ab}$ & $42.14 \mathrm{ab}$ \\
\hline
\end{tabular}

Averages followed by the same letter in column did not differ by the Tukey's test ( $\mathrm{p}>0.05)$.

When we observe the amounts related to the treated wood, we perceive a gradual increase due to the period in which the wood remained in the preservative. While the treatment of 3 days showed results close to non-treated species, the other treatments $(6,9,12$ and 15 days) presented higher values and, thus, an increase in the physical and mechanical properties. These results demonstrates the proportionality between period of treatment and wood properties. 


\section{DISCUSSION}

\section{Efficiency of preservative treatment}

Regarding non-industrial methods, such as the sap replacement, full penetration of the sapwood over the length of the parts is hardly obtained (PAES et al., 2014a). However, Paes et al. (2007) defined penetrations higher than $10 \mathrm{~mm}$ as sufficient. The treatment had deeper penetration in the base of the pieces. This result is considered advantageous, since this position is the most favorable to the development of wood destroying organisms in pieces installed in the ground, as mentioned by Torres et al. (2011). According to Paes et al. (2014b), the highest values for retention in the base can be explained by its contact with the preservative solution. As the lower portion remains submerged, it is the first to translocate water and absorb the preservative. Thus, it distributed the preservative irregularly through the rest of the part by capillarity.

According to Farias Sobrinho et al. (2005), woods with retention of 4.0 to $6.5 \mathrm{~kg}$ of ia. $\mathrm{m}^{-3}$ can be used in structures out of direct contact with the soil, as long as they receive reinforcement on their top. The treatment of 3 days and all periods for middle and top showed inferior results in comparison to those mentioned by the authors. Only the base showed results for the period of 6 days

It is possible to understand the lack of homogeneity in the results if we consider the non-realization of the inversion process of fence posts during the treatment (TORRES et al., 2011). This process did not occur in order to enable the assessment of the effect of capillarity. According to the authors, the technique provides greater protection for the material. Meanwhile, the upper part deterioration of the piece by physical agents due to exposure to the environment favors the appearance of wood decay organisms.

\section{Weight loss}

The weight loss of Hovenia dulcis wood, with no preservative treatment (control), was considered as moderately resistant in relation to the natural forest environment, according to the ASTM D-2017 (2005) classification. As reported by Rigatto et al. (2001), this species is resistant in concern with its natural durability. However, when it is in contact with the soil, this wood shows less resistance. In similar research, Modes et al. (2012) pointed the species as resistant in relation to white rotting, under laboratory condition. Ribeiro et al. (2014) stated that the difference for the assessment of the durability in the laboratory and in field test occurs due to the fact that the latter submits the wood to deterioration and degradation risks. These aspects are not contemplated in tests performed in the laboratory.

Even with the treatments, the values found for weight loss are considered high in comparison to those reported by Modes et al. (2012). These results can be explained by the exposure of the samples in the field test, located in a forest area composed by several arboreal, native and planted bodies. The conditions of the forest, especially in relation to the ground, favor the development of microorganism decomposers. The values of total porosity $\left(0.53 \mathrm{~cm}^{-3}\right)$ and bulk density $\left(1.2 \mathrm{~g} \mathrm{~cm}^{-3}\right)$ allow the soil to remain with high levels of humidity, which enables the development of microorganisms even in periods of drought (SILVEIRA et al., 2015). The organic matter content present in the soil $(3.3 \%)$ is considerable and also provides better conditions for the development of organism decomposers (CARVALHO et al., 2016).

\section{Static bending}

Water-borne preservatives, for example, their formulation copper, arsenic and ammonia, react with the wood. When used in certain situations, such as no pressure treatments (sap displacement), these products may reduce its mechanical properties by promoting corrosion of mechanical fasteners (KRETSCHMANN, 2010). The high reduction of mechanical features is related to the exposure environment, even if the wood has undergone preservative treatment. In similar work, Vivian et al. (2014) found that samples set up in the forest deteriorated more than others did. These results relate to inherent edaphoclimatic characteristics of the forest environment that favor diversity and activity of decomposing wood organisms.

The high rate of wood decomposition in the forest environment is influenced by the higher humidity of the forest, as well as by the higher water storage capacity of the soil. It is also influenced by the little sunlight transmission through the canopy, which provides low luminosity and temperatures in the field environment (MELO et al., 2010).

\section{CONCLUSIONS}

- The treatment time of, at least, 15 days is indicated for the Hovenia dulcis species, since it was the only period that provided penetration and retention values within the pre-established norms. It corresponds to the region of base of round fence posts.

- The treatment with CCB provided greater behavior performance rate than treatments in accord with weight 
loss. It presented satisfactory values after exposure to the field and changed its rate from moderate to resistant.

- The assessment of the static bending revealed a significant reduction in stiffness and resistance of the wood after the field test period, even when the wood was treated. It demonstrates that the forest environment promoted the process of wood decomposition

\section{REFERENCES}

AMERICAN SOCIETY FOR TESTING AND MATERIALS. ASTM D - 2017: standard method for accelerated laboratory test of natural decay resistance for woods. West Conshohocken, 2005. 5 p.

AMERICAN SOCIETY FOR TESTING AND MATERIALS. ASTM D - 143: standard test methods for small clear specimens of timber. West Conshohocken, 2005. $31 \mathrm{p}$.

ASSOCIAÇÃO BRASILEIRA DE NORMAS TÉCNICAS. NBR 6232: penetração e retenção de preservativos em madeira tratada sob pressão. Rio de Janeiro, 2013. 16 p.

CARVAlHO, D. E.; MARTINS, M. A. P.; SANTINI, E. J.; FREITAS, L. S.; TALGATTI, M.; SUSIN, F. Natural durability of Eucalyptus dunnii Maiden, Eucalyptus robusta Sm., Eucalyptus tereticornis Sm. AND Hovenia dulcis Thunb. wood in field and forest environment. Revista Árvore, Curitiba, v.40, n.2, p. 363-370, 2016.

CLAUSEN, C. A.; GLASS, S. V. Build green: wood can last for centuries. Madison: US Department of Agriculture, Forest Service, Forest Products Laboratory, 2012. 24 p. (General Technical Report FPL-GTR-215).

FARIAS SOBRINHO, D. W.; PAES, J. B.; FURTADO, D. A. Tratamento preservativo da madeira de algaroba (Prosopis julifora (Sw) D.C.), pelo método de substituição de seiva. Cerne, Lavras, v.11, n. 3, p. 225-236, 2005.

KRETSCHMANN, D. E. Mechanical properties of wood. In: Wood handbook: wood as an engineering material. 100 ${ }^{\text {th }}$ ed. Madison: U.S. Department of Agriculture, Forest Service, Forest Products Laboratory. 2010, p. 5.1-5.46. (General Technical Report FPL-GTR-190).

LIIBERT, L.; TREU, A.; MEIER, P. The Fixation of new alternative wood protection systems by means of oil treatment. Materials Science, Kaunas, v. 17, n. 4, p. 402-406, 2011.

MELO, R. R.; STANGERLin, D. M.; SANTINI, E. J.; HASELEIN, C. R.; GATTO, D. A.; SUSIN, F. Durabilidade da madeira de três espécies florestais em ensaios de campo. Ciência Florestal, Santa Maria, v. 20, n. 2, p. 357-365, 2010.

MILANI, C. J.; KRIPKA, M. A identificação de patologias em pontes de madeira: diagnóstico realizado no sistema viário do município de Pato Branco - Paraná. Revista Eletrônica de Engenharia Civil, v. 1, n. 4, p. 2333, 2012. Available in:< http://revistas.ufg.br/index.php/reec/article/view/17726/11290 > Accessed in: 05 jun. 2015.

MODES, K. S.; BElTRAME, R.; VIVIAN, M. A.; SANTINI, E. J.; HASELEIN, C. R.; SOUZA, J. T. Combinação de dois métodos não industriais no tratamento preservativo de moirões de Eucalyptus grandis. Ciência Florestal, Santa Maria, v. 21, n. 3, p. 579-589, 2011.

MODES, K. S.; LAZAROTTO, M.; BELTRAME, R.; VIVIAN, M. A.; SANTINI, E. J.; MUNIZ, M. F. B. Resistência natural das madeiras de sete espécies florestais ao fungo Pycnoporus sanguineus causador da podridão branca. Cerne, Lavras, v. 18, n. 3, p. 407-411, 2012.

PAES, J. B.; MELO, R. R.; GUEDES, R. S.; SOUZA, P. F. Tratamento preservativo de peças roliças de leucena (Leucaena leucocephala (Lam.) de Wit.) pelo método de substituição da seiva. Revista de Ciências Agrárias, Recife, v. 47, n. 1, p. 231-246, 2007.

PAES, J. B.; MELO, R. R.; LIMA, C. R; GUEDES, R. S. Eficiência do tratamento preservativo na resistência da madeira de leucena (Leucaena leucocephala (Lam.) de Wit.) a organismos xilófagos. Revista Florestal Venzolana, Mérida, v. 52, n.1, p. 85-91, 2008.

PAES, J. B.; SANTOS, G. C.; MELO, R. R.; LIMA, C. R.; NICOLAU SOBRINHO, W. Efeito da inversão no tratamento de moirões submetidos ao método de substituição da seiva. Ciência Florestal, Santa Maria, v. 24, n. 1, p. 211-221, 2014a.

PAES, J. B.; LOPES, D. J. V.; GONÇALVES, F. G.; BRITO, F. M. S.; LOMBARDI, L. R. Efeito da Concentração na ascensão de soluções preservativas preparadas com CCB em moirões

FLORESTA, Curitiba, PR, v. 48, n. 1, p. 59-66 jan./mar. 2018.

Silveira. A. G. et al.

ISSN eletrônico 1982-4688

DOI: $10.5380 /$ rf.v48 i1.50118 
de Eucalyptus. Floresta e Ambiente, Seropédica, v.21, n.3, p.384-393, 2014b.

RIBEIRO, M. A.; STANGERLIN, D. M.; SOUZA, A. P.; CARDOSO, G. V; CALEGARI, L.; GATTO, D. A. Durabilidade natural da madeira de jequitibá em ensaios de deterioração em campo aberto e floresta durante as estações de seca e chuva. Comunicata Scientiae, Bom Jesus, v. 5, n. 4, p. 402-411, 2014.

RIGATTO, P. A.; PEREIRA, I. C. D.; MATTOS, P. P.; SCHAITZA, E. G. Características físicas, químicas e anatômicas da madeira de Hovenia dulcis. Colombo: EMBRAPA Florestas, 2001, 4p. (Comunicado Técnico, 66).

SILVEIRA, A. G.; SANTINI, E. J.; TREVISAN, R.; CANCIAN, L. C.; MARIANO, L. G. Ocorrência e danos de térmitas na madeira de Acacia mearnsii (Fabaceae) em dois campos de apodrecimento (Nota Científica). Revista do Instituto Florestal, São Paulo, v. 27, n.2, p. 183-189, 2015.

TORRES, P. M. A.; PAES, J. B.; LIRA FILHO, J.A.; NASCIMENTO, J. W.B. Tratamento preservativo da madeira juvenil de Eucalyptus camaldulensis Dehnh. pelo método de substituição de seiva. Cerne, Lavras, v. 17, n. 2, p. 275-282, 2011.

VIDAL, J. M.; EVANGELISTA, W. V.; SILVA, J. C.; JANKOWSKY, I. P. Preservação de madeiras no Brasil: histórico, cenário atual e tendências. Ciência Florestal, Santa Maria, v. 25, n. 1, p. 257-270, 2015.

VIVIAN, M. A.; MODES, K. M.; BELTRAME, R.; SOUZA, J. T; STANGERLIN, D. M.; MORAIS, W. W. C.; SANTINI, E.J. Influência do tratamento térmico nos defeitos de secagem da madeira de Hovenia dulcis Thunb. Ciência da Madeira, Pelotas, v. 2, n. 1, p.15-28, 2011.

VIVIAN, M. A.; SANTINI, E. J.; MODES, K. S.; CARVALHO, D. E.; MORAIS, W. W. C. Resistência biológica da madeira tratada de duas espécies de Eucalyptus em ensaio de campo. Pesquisa Florestal Brasileira, Colombo, v. 34, n. 80, p. 1-

9, 2014. 